\title{
Correspondence
}

\section{Storage of corneal donor material}

\section{To the Editorial Committee of the British Journal of Ophthalmology}

SIRS,- - In his interesting article "Experiments on Canine Corneal Donor Material Stored in Liquid Nitrogen" (Brit. F. Ophthal., I968, 52, 649), Dr. F. O. Mueller comments on the histochemical tests on the endothelium of stored human cornea. These tests showed severe endothelial changes in contrast to the good results obtained when grafting such material. He describes the technique used for assessing endothelial viability, a technique almost identical to that used by O'Neill, Mueller, and Trevor-Roper in earlier experiments (Brit. 7. Ophthal., 1967, 51, 13). In these tests the cornea is incubated with nitroblue tetrazolium and the amount of mitrochondrial staining is considered to be an indication of the lack of viability. This conclusion is one with which we cannot agree.

The tetrazolium dyes demonstrate the presence of various parts of the Krebs cycle, depending on the substrate used. Thus, staining of the cell demonstrates only a functional Krebs cycle and this per se demonstrates a viable cell.

Mueller and O'Neill have used the dye as a test of membrane permeability. There is no evidence quoted to show that the permeability of the endothelial cell membrane is identical or even similar to that of the mitochondrial membrane. A small hole in the cell membrane may allow dye to enter the cell and formazan will be deposited if, and only if, the enzymatic reductive processes are intact. If the cell were dead, then presumably formazan would not be precipitated at all; thus this test demonstrates only a damaged cell and certainly does not indicate that the cell is dead. While accepting that the results published are correct because of the valid comparisons which have been made, I feel that a theoretical objection does exist to the use of nitroblue tetrazolium as described by Mueller.

The presence of a damaged yet viable cell, which can recover its function, could also explain the contrary findings which Mueller commented on in the paper, viz. the lack of correlation between the histochemical results and the results of grafting of the thawed-out material.

BARAGWANATH HOSPITAL, JOHANNESBURG

Yours faithfully,

UNIVERSITY OF THE WITWATERSRAND, SOUTH AFRIGA

B. S. Kuming

February 6, 1969

\section{To the Editorial Committee of the British Journal of Ophthalmology}

SIRs,--Thank you for giving me the opportunity of commenting on Dr. Kuming's letter.

I do agree with Dr. Kuming that the presence of a damaged yet viable cell which can recover its function could explain the contrasting findings and the lack of correlation between histochemical results (nitroblue tetrazolium staining) and the results of grafting.

In our earlier experiments (O'Neill, Mueller, and Trevor-Roper, Brit. J. Ophthal., ig67, 51, I3), we concluded that cells which showed dense di-formazan deposits had suffered irreversible damage. However, I have since come to the conclusion that it is difficult to assess the degree of pathological changes by this histochemical staining method. In my recent paper (Brit. J. Ophthal., 1968, 52, 649), I said only that the results on thawed-out human cornea were suggestive of severe endothelial changes when compared with fresh material, which meant that some pathological changes must have occurred, the degree of which can be assessed only by comparison and by grafting.

ROYAL FREE HOSPITAL, LONDON, W.C.I

Yours faithfully, March 2, 1969 